\title{
KÂNÛNÎ'YE İTHAF EDİLEN UMÛR-I ÂMME RISÂLESİ: ÖZGÜLÜK TEMELLİ YORUM BAĞLAMINDA BİR KATKI
}

\author{
Yasin APAYDINa
}

Öz

Bu çalışma, Kanûnî Sultan Süleyman'a (1520-1566) ithaf edilen müellifi meçhul bir umûr-ı âmme risâlesini merkeze alarak umûr-ı âmme sorununa odaklanmaktadır. Fahreddîn Râzî ile başlayan dönem ve sonrasında kaleme alınan felsefe ve daha özelde kelâm eserlerinde müstakil bir bașlık hüviyetine kavuşan umûr-ı âmme, tanımlanmasına ve kapsamına yönelik birtakım farklı fikirlerin öne sürüldüğü bir alan olmuștur. Bu tanımlama çabaları arasında etkisini sonraki yüzyıllarda da gösteren ve kendine birçok taraftar bulanı özgülük temelli yorumdur. Umûr-ı âmmenin ne olduğu sorusunu mevcudun kısımlarıyla irtibatlı bir șekilde özgü olmamak șeklinde yanıtlayan bu anlayıș, özgü olmamanın hangi yönde ve ne șekilde gerçekleșeceği hususlarındaki görüş farklılığı neticesinde düşünürlere göre değişkenlik göstermiştir.

XVI. yüzyılda kaleme alınan ve müellifine dair bir kayda rastlanmayan umûr-1 âmme risâlesi, Îcî tarafından el-Mevâkıf'ta dile getirilen özgülük temelli yoruma yeni ve farklı bir açılım getirme, hem mahiyet hem de kapsamı cihetiyle umûr-ı âmmeyi daha önceki alımlanış tarzlarından farklı ele alma iddiası taşımaktadır. Makale, XV. ve XVI. yüzyıllarda Osmanlı topraklarında umûr-ı âmmeye dair tartışmaların bağlamını ortaya koyma ve zikredilen risâlenin başta özgülük temelli tanımı olmak üzere diğer bakış açılarından ne oranda ayrıştığını göstermeyi hedeflemektedir. Ayrıca ele alınan konuların zeminini teşkil eden risâle metninin günümüze ulaşan tek nüshasından hareketle yapılan neşri ve tercümesi çalışmanın sonunda ek olarak sunulmaktadır.

Anahtar kelimeler: İslam Felsefesi, Osmanlı Felsefesi, Umûr-ı âmme risâlesi, Şerhu'l-Mevâkıf, Hatibzâde.

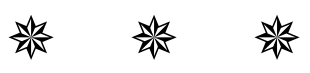

a Dr., İstanbul Üniversitesi, yasin.apaydin@istanbul.edu.tr 


\section{AN ANONYMOUS TREATISE ON AL-UMUR AL-AMMAH DEDICATED TO SULTAN SULEYMAN THE LAWGIVER: A NEW PERSPECTIVE IN THE CONTEXT OF INTERPRETATION OF IRREDUCIBILITY}

This article focuses on al-umūr al-āmmah (general metaphysics) discussed in an anonymous treatise dedicated to Suleymān the Lawgiver (1520-1566). By the time of al-Rāzì (d. 606/1210) al-umūr al-ämmah sections began to take a central position in philosophical and theological works. It became an independent field of study in which its meaning and scope was refined. What makes a concept belonging to the class of concepts known as al-umür al-ämmah is whether or not it is peculiar to one of the three parts of existence namely necessary, substance or accident. There were variying views according to the philosophcal and theological diversity among thinkers in defining the direction of irreducibility.

The anonymous author of the treatise claims that the reception of the theory of irreducibility was not appropriate with its original form introduced primarily by al-Īci in his al-Mawāqif. In this context, the article aims to show that the outlook of al-umūr al-āmmah during the XIV and XV centuries of Ottoman Empire put forward a distinctive interpretation of the theory of unpeculiarity. Additionally the text and the translation of the treatise is attached at the end of the article.

[The Extended Abstract is at the end of the article.]

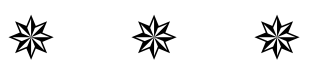

\section{Giriş}

Müteahhirûn dönemde felsefe-kelâm alanında telif edilen eserler, önceki dönemde kaleme alınanlardan birtakım hususlar açısından ayrışmaktadır. Ele alınan konular, konuların işleniş biçimi ve dile getirilen üslup önceki döneme göre farklılaşmış olup bu duruma erken dönemden itibaren muhtelif düşünürler tarafından işaret edilmiștir. ${ }^{1}$ Söz konusu farklılaşma en bariz şekilde, çoğu zaman eserlerin umûr-ı âmmeye tahsis edilen kısımlarıdır.

Lugavî anlamıyla "genel şeyler" olarak karşılayabileceğimiz umûr-ı âmme, içerdiği anlamlar itibarıly "genel durumlar" ya da "ontolojinin temel kavramları" șeklinde Türkçe ve diğer dillere tercüme edilmiştir. Umumiyetle varlık, birlik, mahiyet gibi tek kavramlar ya da kıdem-hudûs, birlik-çokluk, küllî-cüzî̂, illet-ma'lûl gibi kavram çiftleri umûr-ı âmme başlığı altında

1 Tașköprîzade, Miftâhü's-Sa'âde ve Misbâhü's-Siyâde fi Mevzûâti'l-'Ulûm (Beyrut: Dâru'lkütübi'l-'ilmiyye, 1985), 1/294; İbn Haldun, Mukaddimetü İbn Haldun, thk. Mustafa Şeyh Mustafa, (Beyrut: Müessesetü'r-Risâle Nâşirûn, 2007), 534; Tâcüddîn Sübkî, Mu'îdü'nni'am, nşr. Harun Yılmaz-Muhammed Enes Midilli (İstanbul: Türkiye Yazma Eserler Kurumu Başkanlığı Yayınları, 2019), 144. 
incelenmiştir. Üzerinde ittifak edilen bir tanımı olmamakla birlikte umûr-ı âmme, mevcut olmak bakımından mevcuda, diğer bir tabirle metafiziğin mevzuuna ilişen zâtî arazlar olarak tanımlanmıştır. ${ }^{2}$ Dolayısıyla onlar metafiziğin meseleleri yani aydınlatılması gereken konuları şeklinde görülmüştür.

Sözü edilen durum, metafizikçi düşünürleri umûr-ı âmmenin nasıl tanımlanması ve neleri içermesi gerektiği hususunda mahiyet ve kapsam tartışmasına itmiştir. Bunun neticesinde umûr-ı âmme sorunu olarak isimlendirebileceğimiz bir tartışma alanı vücut bulmuştur. Bu tartışmanın ana taşıyıcısı olan felsefe-kelâm metinlerinin zamanla ders kitapları olarak medreselerde yer almasıyla birlikte umûr-ı âmme sorunu daha geniş çevrelerce ele alınmaya başlamıştır.

Yayıldığı hemen her coğrafyada medrese inşa etmeyi ihmal etmeyen Osmanlı Devleti, medresenin yapılandırılması ve geliştirilmesi adına mühim adımlar atmıștır. Bu adımların başında medreseleri belirli bir hiyerarşi içerisine dâhil etme ve her bir medreseye ait bulunduğu merhalede okutulan metnin isminin verilmesi gelmektedir. ${ }^{3}$ Salt bir isimlendirme olmanın ötesinde seçilen temel metnin ciddi anlamda okunup okutulmasını ve mezun olan öğrencilerin belli konular üzerinde ihtisas sahibi kılınmasını sağlayan bu adım, okutulan eserlerde öne çıkan konular ve problemler etrafında daha detaylı ve kapsamlı tartışmaların yapılmasının önünü açmıştır.

Yukarıda kısaca değindiğimiz umûr-ı âmme tartışması, medreselerde tedris edilen iki temel metnin ortaya koyduğu çerçevede Osmanlı bilginleri tarafından alımlanmıştır. Bu metinlerin ilki, Îcînin (ö. 756/1355) kaleme aldığı el-Mevâkıf ve onun üzerine Cürcânî (ö. 816/1413) tarafından yazılan Şerhu'l-Mevâkıf tır. Bir diğeri ise Nasîruddîn Tûsînin (ö. 672/1274) olgunluk dönemi eseri Tecrîd ve yine Cürcânî tarafından Şemseddîn İsfâhânînnin (ö. 749/1349) Tesdîdü'l-kavâ'id adlı şerhi üzerine kaleme alınan Hâşiyetü'tTecrîd'dir. Her iki metin, birçok Osmanlı âlimi tarafından şerh, hâşiye ve ta'likât çalışmasına konu olmuş, ihtiva ettiği meseleler yeniden ele alınarak öncesinde ya fark edilmemiş ya da fark edilmişse de kısa ve kapalı kalmış cihetleri açımlanarak yeni boyutlar kazanmıştır.

Umûr-ı âmme tartışmasının seyrini takip ettiğimizde Osmanlı'yı

2 İbn Sînâ, Uyûnü'l-hikme thk. Abdurrahman Bedevî, (Kuveyt: Vekâletü'l-matbû'ât, 1980), 47. İbn Sînâ, diğer eserlerinde mevcudun ilișenleri ya da özel ilișenler tabirlerini tercih etmiştir. Bkz. Yasin Apaydın, Metafiziğin Meselesini Temellendirmek: Tecrîd Geleneği Bağlamında Umûr-ı Âmme Sorunu, (İstanbul: Endülüs Yayınları, 2019), 282-283.

3 Cevat İzgi, Osmanlı Medreselerinde İlim: Riyâzî ve Tabiî Illimler (İstanbul: Klasik Yayınları, 2019), 38. 
önceleyen dönemde Fahreddîn Râzî (ö. 606/1210), Necmeddîn Kâtibî (ö. 675/1277), Tûsî (ö. 672/1274), Şemseddîn Semerkandî (ö. 702/1303) ve İsfahânî gibi isimlerin, eserlerinde belirli oranda bu konuyla ilgilendiklerini söyleyebiliriz. Umûr-ı âmmeyi tanımlama girişimleri, kapsamını belirleme gayretleri ve diğer bahisler karşısındaki konumunu tayin etme çabaları bu meyanda zikredilmesi gereken alanlardır. Bununla birlikte konuyu ele alan düşünürlerin umûr-ı âmmenin mesâili olarak görebileceğimiz tek tek umûr1 âmme kavramlarının analizlerini ihtiva eden tartışmalara daha geniş yer verdikleri görülmektedir. Umûr-ı âmmeyi küllî bir kavram olarak görüp doğrudan ona yönelmek yerine genel eğilim ona meseleler bütünü olarak yaklaşma şeklinde olmuştur. Bu durum, umûr-ı âmme meselelerini paranteze alarak doğrudan bir kavram olarak umûr-ı âmmenin kendisini konu edinen ve tartışan açılkamaların çoğu zaman birkaç satırdan öteye gitmediği ürünlerin vücut bulmasını beraberinde getirmiştir.

Yukarıda anılan düşünürler, umûr-ı âmme kavramının kendisini tartışmaya açmakla umûr-ı âmme sorunu ve bunun meydana getirdiği umûr1 âmme literatürünün merkezinde yer almış isimlerdir. Onların kısa da olsa bu soruna dair açıklamaları, umûr-ı âmmenin doğası ve kapsamı konusunda sonraki dönemlerde ortaya atılan görüş ve iddiaların yönlendiricisi olmuştur. Bu sayede ihatası güç, oldukça soyut ve teknik bazı tartışmalar umûr-ı âmme bahislerinin başlarında yer almıştır. Böylece müstakil felsefî bir sorun olarak umûr-ı âmmeden bahsetmek mümkün hale gelmiştir.

\section{A. Osmanlı Dönemi Umûr-ı Âmme Tartışmaları}

Osmanlı dönemine gelindiğinde var olan umûr-ı âmme tartışmalarının hem nicelik hem de nitelik açısından seviye atladığı görülmektedir. Umûr-ı âmme tartışmalarının medrese çevrelerinde geniş yankı bulmasını sağlayan iki metin olan Tecrîd ve Mevâkıf üzerine bu dönemde yazılan onlarca metin tetkik edildiğinde söz konusu durum çok açık bir şekilde ortaya çıkmaktadır. ${ }^{4}$ Özellikle bu iki metin üzerine yazılan şerh ve hâşiyelerin yoğunlaştığı Fatih ve II. Bâyezid döneminde Ahaveyn (ö. 853/1450), Hocazâde (ö. 893/1488), Hatibzâde (ö. 901/1496), Kara Seydî (ö. 912/1507), Samsûnîzâde (ö. 919/1513), Hüsâm Çelebi (ö. 926/1520),

${ }^{4}$ Osmanlı dönemi Șerhu'l-Mevâkıf etrafında olușan literatür için bkz. Mustakim Arıcı, "Bir Otorite Olarak Seyyid Şerif Cürcânî ve Osmanlı İlim Hayatındaki Yeri”, İslam Düşüncesinde Süreklilik ve Değişim: Seyyid Şerif Cürcânî Örneği, ed. M. Cüneyt Kaya (İstanbul: Klasik Yayınları, 2015), 82-90; İsrafil Șen, Şerhu'l-Mevâkıf ve Hâşiyeleri Bağlamında Naklî Delilin Kesinliği Problemi (İstanbul: İstanbul Üniversitesi, Sosyal Bilimler Enstitüsü, Yüksek Lisans Tezi, 2020), 6-28. Tecrîd literatürünün umûr-ı âmme sorununa etkisi için bkz. Apaydın, Metafiziğin Meselesini Temellendirmek, 55-58. 
Şucâeddin İlyas er-Rûmî (ö. 929/1523) gibi isimlerin başını çektiği düşünürler grubu, zikri geçen iki metin üzerine yazdıkları eserlerde umûr-ı âmme sorununu ciddi şekilde tartışmıştır.

Umûr-ı âmmeye dair tartışmalar, bahsi geçen şerh ve haşiyelerle sınırlı kalmamıștır. Yazılan şerh ve haşiyeler zamanla müstakil risâlelere evrilmiştir. Umûr-ı âmmenin doğası ve kapsamını merkeze alan bu risalelerin "umûr-ı âmme risaleleri" olarak isimlendirilmesi mümkündür. Genel olarak şerh ve haşiyelerde kullanılan üsluba yakın bir şekilde, merkeze alınan bir metnin ilgili pasajlarını açımlamaya yönelik telif edilen umûr-ı âmme risaleleri, kimi zaman medresenin açllış dersinin metni olarak kimi zaman da dönemin hükümdarının mütalaasına sunulmak üzere kaleme alınmıştır.

Umûr-ı âmme tartışmalarının odak noktasında iki ismin yer alması dikkat çekicidir. Bunların ilki, tedris edilebilir eserler yazmış olması yanında meseleleri ele alma ve çözme biçimi Osmanlı düşünürlerince genel kabul görmüş Cürcânî'dir. Onun gerek Şerhu'l-Mevâkıf ta Îcî'nin umûr-ı âmme tanımına yönelik açıklamaları ve kapsam konusundaki görüşleri gerekse de Hâşiyetü't-Tecrîd'de İsfahânî ve Tûsînnin umûr-ı âmmeye yönelik yaklaşımlarını yorumlaması sonraki dönemde birçok düşünür için bir problem alanı olarak görülmüş ve tartışmaya açılmıştır. Odak noktasında yer alan ikinci isim, Fâtih ve II. Bâyezid döneminin meşhur müderrisleri arasında yer alan Hatibzâde'dir. Onun özellikle Cürcânî'nin Hâş̧yetü't-Tecrîd'i üzerine kaleme aldığı hâşiye, umûr-ı âmme tartışmalarına çok farklı boyutlar eklemiş ve Osmanlı coğrafyasında birçok ismi bu tartışmanın içine katmaya başarmıştır. ${ }^{5}$

Son olarak siyasi otoritenin umûr-ı âmme tartışmalarının revaç bulmasındaki rolü de yadsınamaz düzeydedir. Çalışmamızın konusunu teşkil eden Umûr-ı Âmme Risâlesi'nin başında da zikredildiği üzere eser, dönemin sultânı Kanûnînnin bizzat "umûr-ı âmmenin evâili"ni mütâlaa etme emri vermesi üzerine vücut bulmuştur. Bu durum, Kanûnî̀ye ya da eserin müellifine has bir durum değildir. II. Bayezid'in bu konuya özel ilgi gösterdiğine dair vesikalar günümüze ulaşmıştır. Bunlardan ikisini umûr-ı âmmenin Osmanlı Felsefesi'ndeki konumunu göstermesi açısından zikretmekte fayda görmekteyiz.

5 Taşköprîzâde, eș-Şekâ'iku'n-nu'mâniyye fî 'ulemâi'd-devleti'l-'usmâniyye, thk. Seyyid Muhammed Tabâtabâî Bahbahânî, (Tahran: Ketabhâne müze ve merkez-i isnâd-i meclis-i şûrâ-yı islâmî, 2010), 137. Kâtip Çelebi, Keşfü'z-zunûn 'an esâmi'l-kütübi ve'l-fünûn, (Ankara: Milli Eğitim Bakanlığı, 1947), 1/346. 
1483 Mayıs'ı tarihini taşıyan bir vesikaya göre, II. Bayezid'in emriyle imtihan maksadıyla Edirne'de dönemin iki mollası Yusuf b. Abdurrahman [ö. ?] ile İbn Abbâsî [ö. ?] arasında kazasker6 ve İzârî Çelebi'nin (ö. 901/1495) de hazır bulunduğu ilmî bir mecliste umûr-ı âmme bahsinin mahiyet bölümüne dair bir tartışma cereyan etmiştir. ${ }^{7}$ Taraflar Cürcânî'nin yazdığı başta olmak üzere Tecrîd haşiyelerinden deliller sunarak konu hakkında mülahazalarını belirtmiştir. İlk tartışmacının kaleminden çıkan tartışma metninin kenarında müellife ait minhuvât kayıtları yer almaktadır. Bu kayıtlara göre, Sultân'ın umûr-ı âmme bahsinden ilgili kısmın tartışılmasını özellikle arzu etmesi, ya hocası Muarrifzâde'den ${ }^{8}$ (ö. [?]) nakledildiği üzere imtihanın gerçekleștiği vakit mezkûr bahsi ders olarak almış olması ya da tartışmaya katılan mollalardan hangisinin medreseye atanmayı hak ettiğini belirlemeye matuftur. ${ }^{9}$

Bahsi geçen belgeden yola çıkarak Osmanlı sultanlarının umûr-ı âmmeye dair bahisleri tahsil ettikleri ve bunları medreseye atama imtihanlarında kriter olarak tayin etme iradesine sahip olduklarını söylemek mümkündür.

II. Bayezid'in huzurunda umûr-ı âmme ile ilgili tartışmaların dönemin âlimleri tarafından da devam ettirildiği görülmektedir. Bu tartışmaların en aktif katılımcllarından biri olan Molla Lutfi (ö. 900/1495), daha sonra bizzat Sultan'ın emriyle yazıya aktarıp es-Seb'u'ş-şidâd adını verdiği risâlesinde, tartışılan konuların ilki Cürcânî'nin Hâş̧iye 'alâ Şerhi'l-Metâli'de yer verdiği felsefe tanımı ve felsefenin konusu ile ilgili olup bu bahis içerisinde umûr-ı âmmenin mahiyeti ve kapsamı ele alınmaktadır. ${ }^{10}$

Bu iki örnek birlikte değerlendirildiğinde Osmanlı âlimlerinin umûr-ı âmme konusuna eğilmelerini siyasi otorite tarafından da desteklemiş ve bu çerçevede tartışma ortamının meydana getirilmesinde etkili bir rol oynamıştır. II. Bayezid'in bu tutumu torunu Kanûnî tarafından da sürdürülmüş gözükmektedir. Nitekim neşrini gerçekleştirdiğimiz Umûr-ı

60 dönem dikkate alındığında ismi verilmeyen kazaskerin Mevlânâ Muslihuddin ya da Hacıhasanzâde Efendi'den biri olması gerekir. Bkz. Mehmet İpşirli, "Hacıhasanzâde Efendi", Türkiye Diyanet Vakfi İslâm Ansiklopedisi, (İstanbul: TDV Yayınları, 1996), $14 / 503$.

7 Tartışmanın metni için bkz. Yusuf b. Abdurrahman, Fevâid müte'allika bi'l-umûri'l-âmme (İstanbul: Beyazıt Kütüphanesi, Veliyüddin Efendi, 2186), 160a-162b.

8 II. Bayezid'in hocası olması itibarıyla "muallimü's-sultân” lakabıyla bilinmiștir. Bkz. Taşköprîzâde, Şekā'ik, 375.

9 Yusuf b. Abdurrahman, Fevâid müte'allika bi'l-umûri'l-âmme 160a.

10 Tartışma metni için bkz. Molla Lutfi, es-Seb'u'ş-şidâd (İstanbul: Süleymaniye Kütüphanesi, Carullah, 1341), 101a. 
Âmme Risâlesi de, belirtildiği üzere onun desteğiyle hatta emri üzere yazılmıştır.

\section{B. Anonim Umûr-ı Âmme Risâlesi: Mahiyet ve Muhteva}

Bildiğimiz kadarıyla günümüze tek nüshası ulaşan ve mukaddimesinden Kanûnîye ithaf edildiğini öğrendiğimiz Umûr-ı Âmme Risâlesi, müstakil bir şekilde umûr-ı âmme sorununa dair kaleme alınmış eserlerdendir. Yazarının kimliğine dair ne yer aldığı mecmuada ne de eserin herhangi bir yerinde bilgi yer almaktadır. Bununla birlikte yazar olarak herhangi bir ismi tayin edemesek de bazı ipuçları üzerinden tayin alanını daraltmak mümkündür.

Eserin müellifi, telif sebebini zikrettiği mukaddimede "adalet ve ihsan dağıtan” olarak tanıttığı Kanûnî tarafından umûr-ı âmmenin başlarını (evâil) mütâlaa emrinin kendisine tevdi edilmesi üzerine eserini meydana getirdiğini belirtmektedir. Bu durum eserin yazarı ile Kânûnî arasında yakın bir irtibatın olma ihtimalini öne çıkarmaktadır. Müellife verilen bu görev, onun umûr-ı âmme alanına vukufiyetinden olsa gerektir. Nitekim bu husus, ileride de gösterileceği üzere risâlenin muhtelif yerlerinde açıç̧a görülmektedir.

Risâlenin müellifi, kendi eserlerine herhangi bir atıfta bulunmamıştır. Yine de umûr-ı âmme ya da risâlede merkeze aldığı Şerhu'l-Mevâkıf ile ilgili başka çalışmalar yapmış olması muhtemeldir. Risâlenin başlarında umûr-ı âmme tahliline girişmeden önce çok sık rastlanmayan bir tarzda İbnü'lHâcib'in (ö. 646/1249) el-Kâfiye fi'n-nahv'inden iktibas ve istişhatta bulunmasından hareketle müellifin dil ilimlerine karşı özel bir ilgisinin olduğunu söyleyebiliriz.

Eserin yazım tarihine ilişkin nüshanın sonunda herhangi bir bilgi mevcut değildir. Kânûnî döneminde yazılmış olmasına binaen XVI. yüzyılın ikinci ya da üçüncü çeyreğinde kaleme alındığını bildiğimiz eser, kısa olmakla birlikte umûr-ı âmmenin mahiyeti ve kapsamına dair dikkate değer bilgiler ihtiva etmektedir. Bir sonraki başlıkta açıklanacağı üzere, müellifin "yeni" olarak takdim ettiği yorumu, umûr-ı âmme sorununun tarihi seyri açısından önem arz etmektedir.

Mukaddimesinde yer alan "umûr-ı âmmenin başları" ifadesi ile tam olarak ne kastedildiği açı değilse de eserin muhtevası incelendiğinde, o dönem medreselerinde umûr-ı âmme bahislerinin okutulduğu eserlerin başı anlamına geldiği anlaşılmalıdır. Söz konusu risâle bağlamında bu eserin Şerhu'l-Mevâkıf olduğunu söylemek mümkündür. Zira risâle boyunca mezkûr eserden alıntılar eşliğinde meseleler ele alınmakta ve olumlu ya da olumsuz 
hükümlere yer verilmektedir.

Risâle, müellifin el-Mevâkı $\rho$ tan alıntıladığı umûr-ı âmme tanımı ve buna dair getirdiği bir yorum ile başlamakta, özellikle Cürcânî ve Hatibzâde'nin bu tanıma dair zikrettikleri yorumların kısmi eleştirisi ile devam etmektedir. Müellif Cürcânî̀yi yer yer eleştirmekle birlikte daha öncesinde Samsunîzâde ve Hüsam Çelebi'nin Tecrîd haşiyelerinde de gördüğümüz uzlaştırmacı tavrı sürdürmektedir. Diğer bir tabirle 0 , Cürcânî'nin muhtelif eserlerinde yer verdiği umûr-ı âmme tanım ve yorumlarına dair yaptığı tercih farklılı̆̆ını bir çelişkiye irca etmeksizin aralarını uzlaştırarak anlamaya çalışmıştır. Bu durum onun Cürcânîye bütünüyle olumlayıcı baktığı anlamına gelmemelidir. Hem umûr-ı âmmenin tanımı hem de kapsamına dair Cürcânî tarafından Şerhu'l-Mevâkıf, Hâşiyetü'tTecrîd ve Hâşiye 'alâ Şerhi'l-Metâli'de dile getirilen görüşler müellif tarafından tenkit süzgecinden geçirilerek ele alınmış, zayıf ya da şüpheli yönleri varsa açığa çıkarılmıștır.

Müellif tarafından risâlede adı anılıp eleștirilen bir diğer isim Hasan Çelebi'dir (ö. 891/1486). Onun Şerhu'l-Mevâkıf üzerine yazdığı hâşiyede mahiyetin umûr-ı âmmeden sayılıp sayılmayacağı sorununa ilişkin cevabına yer veren müellif, bu cevabı "şüpheli" olarak değerlendirmiş ve gerekçesini ortaya koyarak risâlesini tamamlamıștır.

Müellif, bahsi geçen isimlere dair eleştirilerini umûr-ı âmmenin mahiyetine dair ortaya koyduğu ve "daha önceki şârih ve muhaşşilerin farkına varmadığı"nı iddia ettiği kendi yorumuna dayandırmıştır. Haddizatında risâle, bütünüyle bu noktanın aydınlatılması ve onu dayanak noktası alıp diğer görüşlerin eleştirisinden müteşekkildir. Zikredilen sebepten dolayı biz de bir sonraki başlıkta, umûr-ı âmmenin anlaşılmasına yönelik müellif tarafından sunulan bu katkıyı göstererek dile getirdiği bazı eleştirilere daha detaylı bir şekilde yer vereceğiz.

\section{Umûr-ı Âmme Sorununa Özgülük Yorumu Bağlamında Bir Katkı}

\section{1. Özgülük Yorumu}

Umûr-ı âmme, muhtelif düşünürler tarafından farklı yorumlama ve anlama çabalarına konu olmuştur. Bunların başında birçok düşünür tarafından kabul gören ve yeni yorumlara konu olan özgülük anlayışıdır. Bu anlayışı en açı görebileceğimiz yerlerin başında Îcînin Mevâkı $f_{1}$ gelmektedir. 0, eserinin ikinci bölümünü (mevklf) umûr-ı âmmeye tahsis etmekte ve bu konuyla ilgili meselelere geçmeden önce bir tanım vermektedir. Buna göre umûr-ı âmme, mevcudun kısımları olan Zorunlu, 
cevher ve arazdan birine özgü olmayanlardır.11

Özgü olup olmamayı merkeze alması ve bir kriter olarak vaz etmesi sebebiyle bu anlayışı özgülük yorumu şeklinde isimlendirmek mümkündür. Îcînnin dile getirdiği bu yorum, mevcudun kısımları ile umûr-ı âmme arasındaki ilişkide kapsayıcılık ya da karşıtlık değil de özgü olmamayı öne çıkarmakta, bir şeyi umûr-ı âmme kılan özelliği ve dolayısıyla umûr-ı âmmeye dâhil olmanın ölçütünü de özgü olmama şeklinde vaz etmektedir. $\mathrm{Bu}$ anlayışın bir sonucu olarak mevcutların kısımlarından sadece birinde bulunan durumlar umûr-ı âmme dışında kalmakta, bu üç kısımdan birine özgü olmayıp diğerinde/diğerlerinde de bulunan şeyler umûr-ı âmmeden addedilmektedir.

Umûr-ı âmmenin anlaşılmasına yönelik dile getirilen bu yorum, kapsam ve sınırları tayin hususunda bazı problemleri beraberinde getirmiştir. Umûr-ı âmmeyi müstakil bir başlık açarak ele alan ve bu hamlesiyle kendisinden sonraki literatürü ciddi şekilde etkileyen Fahreddin Râzî ve umûr-ı âmmenin tanımını ve alt kısımlarını teorik bir şekilde ele alarak belirli bir yapıya kavuşturan Kâtibî'nin çabaları ile varlık, mahiyet, birlik, çokluk, zorunluluk, imkân, kıdem ve hudûs gibi kavramlar umûr-ı âmme içinde değerlendirilen kavramlar haline gelmiştir. ${ }^{12} \mathrm{Bu}$ durum beraberinde umûr-ı âmme kavramlarının zaptedilmesi problemini ortaya çıarmıştır. Düşünürler zikredilen kavramların umûr-ı âmme içinde değerlendirilmesini muhtelif yön ve kriterlere bağlayarak açıklamaya çalışmıştır.

Umûr-ı âmmeyi zaptetmeye yönelik açıklamalar, umûr-ı âmmenin sınırlarını belirleme, içine alması gereken kavramları tayin etme ve dışarıda bıraktıklarının gerekçesini sunmayı içermiştir. Özgülük yorumu zaviyesinden bakıldığında Îcînin dile getirdiği tanımın mevcudun tek bir kısmına özgü olan zâtî zorunluluk ve kıdemi dışarıda bırakması gerektiği başta şârih Cürcânî tarafından dile getirilmiştir.13 Ona göre Îcî tarafından zikredilen özgülük yorumu, Zorunlu'ya özgü bu iki durumu umûr-ı âmmenin dışında bırakmakta ve ele alınmasını ikincil hale getirmektedir. Nitekim

11 Îcî, el-Mevâklffí 'ilmi'l-kelâm (Beyrut: Âlemü'l-kütüb, ts.), 41.

12 Kâtibî, umûr-ı âmme ile umûr-ı âmme mesâbesinde olanları ve umûr-ı âmmenin türleri mesabesinde olanları birbirinden ayırt etmektedir. Ona göre, ilki zâtında zorunlu ile zâtında mümkün olan arasındaki ortak şeylerdir. İkincisi, mevcutların çoğunda ortak olan şeylerdir. Sonuncusu ise emr-i 'âmm'ın kendisine taksim olunduklarıdır. Her bir kısmın detaylı açıklaması ve örnekleri için bkz. Kâtibî, el-Münassas fî Şerhi'l-Mülahhas (İstanbul: Süleymaniye Kütüphanesi, Șehit Ali Pașa, 1680), 187b.

${ }^{13}$ Cürcânî, Şerhu'l-Mevâkıf (İstanbul: Matbaa-i Âmire, 1311) 1/215. 
Cürcânî, özgülük yorumunun sebebiyet verdiği bu duruma düşmeyecek alternatif bir tanım da dile getirmekte, mukabili ile birlikte ele alındığında tüm kavramları kapsayacak olanların da umûr-ı âmmeye dâhil olabilme imkânını ortaya koymaktadır.

Cürcânî̀nin Îcî tarafından dillendirilen tanıma karşılık alternatif arayışı Hâş̧iye-i Tecrîd'de de görülmektedir. Cürcânî, İsfahânî'nin umûr-ı âmmeyi kapsayıcılık tanımı üzerinden açıklamasını az önce bahsi geçen karşıtllk yorumuyla tamamlamakta ve bunu daha doğru bir görüş olarak sunmaktadır. Buna ilave olarak o, Îcînin özgülük yorumunu "denildi ki" şeklinde alternatif ama zayıf bir görüş olarak sunmaktadır. ${ }^{14}$

Cürcânî'nin Şerhu'l-Mevâkıf ta kapsayıcllık yorumuna yakınlaştırma, Hâşiye-i Tecrîd'de ise zayıf bir alternatif görüş olarak takdim çabalarına rağmen yine de özgülük yorumunu savunan filozoflar bulunmuştur. Bunların başında Şiraz ve İstanbul'daki felsefe çevrelerini ciddi şekilde etkileyen Ali Kuşçu gelmektedir. 0, Şerhu Tecrîdi'l-'akâid'de umûr-ı âmmeyi "Zorunlu, cevher ve araza özgü olmayanlar" şeklinde tanımlarken ve her bir kısmın kendine has olan durumlarının onlara ait bölümlerde ele alınması sebebiyle müşterek durumların bilgisine yer verilecek müstakil bir bölüme yer açılması zorunluluğunu belirtirken selefi Îcînnin tutumuna oldukça yakın bir tavır takınmıștır. ${ }^{15}$ Kuşçu'ya göre özgülük durumunun yukarıda bahsi geçen zorunluluk ve kıdem gibi durumları dışlayıcılığını bu ikisinin varlığın durumlarından olduğunu belirterek aşmaya çalışmıştır. ${ }^{16}$

Özgülük anlayışı üzerine yorumlar Osmanlı filozofları arasında da devam etmiştir. II. Bayezid dönemi âlimlerinden Kara Seydî (v. 912/1507), umûr-ı âmme sorununa dair yazdığı risâlesinin girişinde umûr-ı âmme terkibini tahlil etmektedir. Ona göre, genellik ifade eden "âmm" lafzı, özgü olmamayı ifade etmektedir $\mathrm{ki}^{17}$ bu ister mevcudun üç kısmında ister iki kısmında isterse de Tanrı'nın zâtında sâbit zorunluluk ve kıdem

14 Cürcânî, Hâşiyetü't-Tecrîd, II, thk. Eşref Altaș vd. (İstanbul: Türkiye Diyanet Vakfı İslam Araştırmaları Merkezi, 2020), 2/41.

15 Ali Kuşçu, Şerhu Tecrîdi'l-'akâid, thk. Muhammed Hüseyin ez-Zâri'î er-Rıdâyî (Kum: Râid, 2014), 73-74.

16 Kuşçu'ya göre, özgülük yorumu benimsendiğinde tanım dışında kalması muhtemelen olan yokluk varlığın mukabili, imkânsızlık ise yokluğun durumlarından olması sebebiyle umûr-ı âmme kapsamında görülmelidir. Ayrıca o, umûr-ı âmmenin, Tecrîd'de olduğu gibi, belirli bir sayıda tutulmasını tümevarımsal bulduğunu da eklemektedir. Bkz. Kuşçu, Şerhu Tecrîdi'l-'akâid, 74-75.

17 Kara Seydî, umûr-ı âmmeye dair Îcî’nin getirdiği özgülük tanımının, "umûr"a (mukayyed) değil de "âmme"nin (kayd) açıklanmasına yönelik olduğunu düşünmektedir. Bkz. Yasin Apaydın, "Kara Seydî-i Hamîdî ve Umûr-ı Âmmeye Dair Risâlesinin Tahlil, Tahkik ve Tercümesi”, Darulfunun İlahiyat, 29/2 (2018), 21. 
örneklerinde olduğu gibi sadece bir kısımda bulunmayı içine almaktadır. ${ }^{18}$ Hatta Kara Seydî'ye göre, zikredilen üç ihtimal dışında mevcutların herhangi bir kısmında bulunmayan imkânsızlık ve yokluk dahi bilinegelen durumlar ${ }^{19}$ (el-umûr el-ma'hûde) olması sebebiyle umûr-ı âmme kapsamında yer aldığını belirtir.

\section{Var Olanlara Özgü Olmayıştan Var Olanların Özgü Olmayışına}

Anonim umûr-ı âmme risâlesine gelindiğinde, yukarıda özet bir şekilde dile getirilen özgülük yorumu ve onun etrafında oluşan yan yorumlar ağına farklı bir veçheden bakış sunulduğunu görmekteyiz. Müellif, Îcî'nin özgülük tanımının alternatif bir okumasını yapmakta ve bu okuma sonucu tanım dışı kalması muhtemel durumların tanım kapsamında değerlendirilmesini amaçlamaktadır. Ona göre, özgülük tanımı görünüşte "mevcutların kısımlarından birine özgü olmayanlar" şeklinde bir anlam içermekle birlikte aslında tanım sahibi Îcî, "kısımların özgü olmadığı şeyler"in umûr-ı âmmeye tekabül ettiğini belirtmektedir. Bu durumda risâlenin yazarına göre umûr-ı âmme, Zorunlu, cevher ve araz kısımlarından birine özgü olmayanlar değil tersine bu kısımların özgü olmadığı durumlardır. ${ }^{20}$

Risâle yazarı, zikrettiği anlamın tanımın zahirine kısmen muhalif olması sebebiyle olsa gerek nahivden bir örnek getirmekte ve bu sayede meramını daha net ifade etmeye çalışmaktadır. Buna göre, münâdânın kısımlarından biri olan mendûb bahsinde el-Kâfiye yazarı İbnü'l-hâcib, "mendûb vâ lafzıyla ayrışmaktadır" derken mendûbu vâ lafzına özgü kılmamakta tersine vâ lafzının sadece mendûbta kullanıldığını belirtmek istemektedir. Aksi takdirde mendûb için kullanılan bir başka lafız olan "yâ"nın kapsam dışında kalması gerekirdi ki bunun yanlışlığı herkesçe bilinmektedir. ${ }^{21}$

Görüldüğü üzere, özgülük tanımının ilk akla gelen anlamına karşılık

\footnotetext{
18 Apaydın, "Kara Seydî-i Hamîdî ve Umûr-ı Âmmeye Dair Risâlesinin Tahlil, Tahkik ve Tercümesi", 21-22.

19 Kara Seydî, "el-umûr"un bașındaki tarif harfinin ahd-i hâricî ifade ettiğini ve bunun da ilimde kendisine bir amaç taalluk etmesi açısından halleri araştırılan şeylere göndermede bulunduğunu zikretmektedir. Bkz. Apaydın, "Kara Seydî-i Hamîdî ve Umûr-ı Âmmeye Dair Risâlesinin Tahlil, Tahkik ve Tercümesi", 21.

20 Yazar özgülük temelli tanımın alışılageldik anlamını "umûr-ı âmmenin, mevcutların kısımlarına özgülügünün olumsuzlanması" (selbü ihtisâsi'l-umûri'l-'âmme 'ani'l-kısmi) olarak nitelerken alternatif olarak takdim ettiği anlamı "kısmın umûr-ı âmmeye özgülüğünün olumsuzlanması” (selbü ihtisâsi'l-kısmi 'ani'l-umûri'l-'âmme) olarak nitelemektedir. Anonim Umûr-ı Âmme Risâlesi (Burdur: İl Halk Kütüphanesi, 68), 109a. ${ }^{21}$ Anonim Umûr-ı Âmme Risâlesi, 109b.
} 
biraz da tersinden bir okuma ile sunulan bu alternatif anlayış, yazar tarafından umûr-ı âmme kapsamı dışında kalma ihtimali bulunan durumların da bu kapsamda değerlendirilmesi gerektiğine matuftur. Nitekim risâlenin yazarı, önerdiği anlam ile tanıma yaklaşıldığında üç seçenekte bunun tahakkuk ettiğini zikretmektedir.

1. Mevcutların kısımlarından üçünü de kapsaması. Yazar tarafından bu kısma verilen örnek varlıktır. Zira o, Zorunlu, cevher ve arazın üçünü de kapsayan her üçüne de yüklem olabilen hallerdendir.

2. Üç kısımdan ikisini kapsaması. Yazara göre varlık ve yokluk taraflarının olumsuzlanması ile ortaya çıkan özel anlamıyla imkân (imkân-ı hâs) durumunu bu kapsamda değerlendirmektedir.

3. Mevcutların kısımlarından birini kapsaması. Zâtî zorunluluk ve kıdem, yalnız Zorunlu'ya ilişmesi sebebiyle bu son kısımda yer almaktadır.

Zikredilen üç seçenekten ikisinin umumiyetle kabul gördüğü bununla birlikte son seçeneğin ancak bazı kayıtlarla umûr-ı âmmeden sayılacağı yukarıda gösterilmiști. Risâle yazarını diğer düşünürlerden farklı kılan husus, onun herhangi bir ilave kayda gerek bırakmaksızın bizzat tanımdan yola çıkarak bunun imkânını ortaya koymasıdır. Zira ona göre zikri geçen üç seçenek için de mevcutların kısımlarından birinin umûr-ı âmmeye özgü olmayışından bahsedilebilmektedir. Bu durum ilk iki seçenekte biraz daha açıksa da son seçenek için ilave bir açlklamada bulunan yazar, "zâtî zorunluluk" ve "kıdem"in mevcudun tek bir kısmını kapsaması durumunda da Zorunlu, bu ikisine özgü olmamayı sürdürmekte ve bu durum zikri geçen iki kavramın umûr-ı âmme içinde ele alınmasında yazar tarafından yeterli görülmektedir. ${ }^{22}$

Risâle müellifinin veciz bir şekilde ifade ettiği bu durumu şu şekilde açımlamak mümkündür: Son seçenek dikkate alındığında, zâtî zorunluluk ve kıdem ü Zorunlu'ya özgü durumlar olmaktadır. Bu özgülük, zikredilen kavramlar cihetinden bakıldığında ortaya çıkmaktadır. Şayet bu duruma kavramlar cihetinden değil de kısım olan Zorunlu cihetinden baktığımızda bir özgülükten bahsedilemez. Zira zâtî zorunlu ve kadîm vasıfları Zorunlu için yüklem yapılabildiği gibi mevcutların her üç kısmını ya da Zorunlu ile birlikte bir başka kısmını kapsayan varlık ya da birlik gibi kavramlar/haller de Zorunlu'ya yüklem kılınabilmektedir. Dolayısıyla umûr-ı âmmenin özgülük yorumunda merkeze alınan ve bir kriter olarak sunulan "özgü olmamak" halen geçerliliğini sürdürmektedir. Sonuç olarak bu durumun 
geçerliliğini sürdürmesine dayalı olarak risâle yazarı, hem zâtî zorunluluk hem de kıdemin umûr-ı âmme kapsamında değerlendirilmeyi hak ettiği görüşündedir.

Umûr-ı âmmenin özgülük temelli yorumuna ilişkin katkısını ortaya koyduktan sonra risâle sahibi eleştiri oklarını umûr-ı âmme sorununa dair görüş beyan eden önemli isimlere yöneltmektedir. Bunların başında Cürcânî gelmektedir. Onun hem Şerhu'l-Mevâkı fa hem de Hâsşiyetü't-Tecrîd'de umûr1 âmmenin muhtelif yorumlarına dair getirdiği izahlar sonraki dönem düşünürleri üzerinde ciddi oranda etkili olmuştur. Bu izahları arasında zâtî zorunluluk ve kıdemin umûr-ı âmme kapsamında değerlendirilemeyeceği yer almaktadır. Zira ona göre, "mevcudun kısımlarından birine özgü olmayan" şeklinde Îcî tarafından ortaya konan tanım, üç kısmın tümünü ya da ikisini kapsayanlar kavramların umûr-ı âmme içinde değerlendirilmesini gerekli kılmakta, bu şartı taşımayan yokluk, imkânsızlık, zâtî zorunluluk ve kıdem ise bu kapsamın dışında kalmaktadır. ${ }^{23}$

Risâle yazarı, Cürcânî tarafından getirilen bu izahın musannif Îcînin kastettiği anlamla örtüşmediğini belirtmektedir. ${ }^{24}$ Ayrıca o, Cürcânî̀nin zikri geçen kavramların umûr-ı âmme bölümünde incelenmesinin ancak asıl kavramlara tâbî olarak ve ikincil bir şekilde olduğunu söylerken de Îcî'nin ifadeleriyle uyumsuzluk içindedir. Zira Îcî, umûr-ı âmme ana başlı̆̆ının ilk alt başlığını "varlık ve yokluk" şeklinde tayin etmiş ve bu haliyle başlık, iki kavramdan her birinin kast olunmasını (maksûdiyye) ihtiva etmektedir. ${ }^{25}$

Cürcânî'nin izahları arasında risâlede eleştirilen bir diğer konu, umûr1 âmmenin karşıtlık temelli yorumuyla ilgilidir. Cürcânî, Şerhu'l-Mevâkıf'ta alternatif bir umûr-ı âmme yorumlamasında bulunarak "mefhumları ya tek başına ya da karşıtlık yoluyla içerenler"in bu kapsama dâhil olduğunu zikretmektedir. Öte yandan o, Hâşiyetü't-Tecrîd'de, zikredilen bu yorumu alternatif bir görüş gibi sunmaktan ziyade kendi tercihi olduğunu gösterir şekilde "daha uygun/doğru" görüş olarak takdim etmektedir. ${ }^{26}$ Risâle yazarına göre, Cürcânî̀nin aynı tanımı bir eserinde meçhul bir sîga ile

${ }^{23}$ Cürcânî, Şerhu'l-Mevâkılf, I, 214-215. Cürcânî, benzer bir açıklamaya Hâșiyetü't-Tecrîd'de yer vermektedir. Burada o, İsfahânî'nin umûr-ı âmmeyi kapsayıcılık temelli okuma çabasının bir devamı olarak zorunluluk, kıdem, imkânsızlık ve yokluk kavramlarının aslî değil de arazî olarak araştırıldığını belirtmektedir. Bkz. Cürcânî, Hâşiyetü't-Tecrîd, II, 41.

${ }^{24}$ Anonim Umûr-ı Âmme Risâlesi, 109b.

25 Anonim Umûr-ı Âmme Risâlesi, 110a.

${ }^{26}$ Cürcânî, Şerhu'l-Mevâkılf, 1/215; Cürcânî, Hâşiyetü't-Tecrîd, 2/ 41. Bazı düşünürler, Cürcânî'nin ifadelerindeki farklılığın giderilmesine yönelik uzlaştırmacı tavır sergilemiştir. Bkz. Taşköprülüzâde, Hâşiye 'alâ Hâşiyeti't-Tecrîd (İstanbul: Süleymaniye Kütüphanesi, Ragıp Paşa, 732), 25b. 
alternatif bir görüş gibi sunarken diğer eserinde benimsediğini hissettirecek bir ifadeyle zikretmesinin sebebi açık olmayıp üzerinde düşünülecek bir durumdur. ${ }^{27}$

Risâle yazarının, ortaya koyduğu özgülük temelli yorumdan hareketle eleştirdiği bir diğer isim Hatibzâde'dir. 0, kaleme aldığı Tecrîd haşiyesinde yer verdiği görüşleriyle çokça tartışılmış, Cürcânîye yönelik eleştirileri karşıt düşünürlerin ret ve itirazlarına konu olmuştur. ${ }^{28}$ Bu eleștirilerden biri de Cürcânî̀nin karşıtlık temelli yoruma karşı sergilediği tutumun benzerini özgülük temelli tanıma da göstermesine yöneliktir. Buna göre Cürcânî, Şerhu'l-Mevâkıf ta İcî'nin tercih ettiği özgülük temelli tanıma yer verdikten sonra bahsi geçen karşıtlık temelli alternatif görüşü zikretmekte ve ilave bir yorumda bulunmamaktadır. Öte yandan o, Hâşiyetü't-Tecrîd'de bu kez özgülük temelli yorumdan meçhul bir siga ile bahsetmiştir. Bu durumu Hatibzâde, mezkur iki yorum arasında herhangi bir farklılık olmadığı ancak lafzî düzeyde bir ayrışmadan söz edilebileceği şeklinde yorumlanmıştır. Zira ona göre, tanımlarda yer verilen "mevcutların kısımları" ifadesi görünüşte kısımlardan ziyade barındırdıkları şahsî fertlerin tümünü ifade etse de bunları ihata etmenin ya da kapsayıcılık yorumunun gerektirdiği şekilde çoğunluğu tayin etmenin aklın sınırları dışında kalacağından kısımların kendisine döndüğünü belirtir. Dolayısıyla bu durum Hatibzâde açısından her iki yorumun aynı yere varacağından hareketle anlamca ortak oldukları şeklinde değerlendirilmiştir. ${ }^{29}$

Risâle yazarına göre Hatibzâde'nin her iki tanımı lafzî seviyede farklılaşır görmesi isabetli değildir. Zira ilk tanım, yukarıda da belirtildiği üzere, mevcudun kısımlarının özgü olmaması anlamıyla alındığında zâtî zorunluluk ve kıdemi umûr-ı âmme içinde tutmaktadır. Buna mukabil mevcudun kısımlarının tümünü ya da çoğunu kapsar şekilde ifade edilen ikinci tanım ise bu iki kavramı umûr-ı âmmenin dışında bırakmaktadır. ${ }^{30}$

Umûr-ı âmme risâlesinde ele alınan konulardan biri de umûr-ı âmme ile kastedilenlerin ne olduğudur. Bu sorun risâlede, Cürcânînnin Hâş̧iye-i Metâli'ide yer verdiği umûr-ı âmme tanımına Hatibzâde tarafından getirilen eleştiriye karşı gündeme gelmiştir. Cürcânî, felsefenin "haricî mevcutları araştıran bir ilim" ve "mevcutların durumlarını araştıran bir ilim" şeklindeki iki tanımını zikrederek her iki tanımda da hikmetin konusunun mutlak varlık

${ }^{27}$ Anonim Umûr-ı Âmme Risâlesi, 110a. Bkz. Cürcânî, Hâșiyetü't-Tecrîd, 2/41.

${ }^{28}$ Apaydın, Metafiziğin Meselesini Temellendirmek, 102-105.

${ }_{29}$ Hatibzâde'nin ifadeleri için bkz. Hatibzâde, Hâşiye 'alâ Hâşiyeti't-Tecrîd (İstanbul: Süleymaniye Kütüphanesi, Fatih, 2926),14b.

${ }^{30}$ Anonim Umûr-ı Âmme Risâlesi, 108a. 
ya da haricî varlık gibi tek bir şey olamayacağını aksine arazî bir şeyde diğer bir tabirle mutlak varlık ya da haricî varlıkta ortak olan birden çok şeyin konu olması gerektiğini belirtir. Bu takdirde, mevcutlar arasında ortak olan durumlar (umûr-ı âmme), hikmetin konusunu teşkil eden birden çok şeyle tekil düzeyde ve onları özel varlıklar kılan kayıtlarla kayıtlanmalıdır. ${ }^{31}$

Cürcânî, kendisinde ortaklığın gerçekleştiği durumlar anlamına geldiğini ifade ettiği umûr-ı âmmeye dair şöyle bir itiraz gündeme getirir: Şayet müşterek durumlar umûr-ı âmmeyle özdeş ise bunlar ele alındıkları kısımda mesele değil mevzu konumundadır. Dolayısıyla umûr-ı âmme kısmında, mevcudun kısımları arasında ortak olan durumlar araştırma konusu edilmemektedir. Zira araştırma, yüklemleri konularıyla olumlu anlamda ilişkilendirmek (isbât) anlamına gelmektedir. ${ }^{32}$

Cürcânî mezkûr itiraza cevaben, umûr-ı âmme kısımlarında araştırılanın umûr-ı âmmeye ilișen zâti arazlar olduğunu ve onların da tıpkı umûr-1 âmme gibi ortaklık kabul ettiğini zikreder. Ona göre umûr-ı âmme, ele alındığı kısımda konu olduğunda onun durumlarını araştırmak haricî varlıkların durumlarını araştırmak anlamına gelmemektedir. Bu sebeple Cürcânî, umûr-ı âmmenin "özel varlık kılan kayıtlarla kayıtlanarak haricî varlıklara yüklem kılınanlar" olması gerektiğini belirtmiştir. ${ }^{33}$

Hatibzâde, Hâş̧iye-i Metâli'de yer alan bu ifadeleri yorumlarken umûr1 âmmenin mevcutlara yüklemlenme tarzından bahseder. Ona göre, umûr-1 âmme mevcutlara türetimli/dolaylı (iştikâk) olarak değil de türetimsiz/doğrudan (muvâta'a) yüklem yapılabilenlerdir. ${ }^{34}$ Dolayısıyla umûr-ı âmme dendiğinde, türetimsiz ya da bir diğer tabirle masdar hallere tekabül eden vücut, kıdem, hudûs, illiyet, öncelik vb. değil de türetilmiş halleri olan mevcut, kadîm, hâdis, illet ve önce gelen vb. anlaşılmalıdır. Bunun aksine, yaygın kullanım zikredilen lafızların masdar halleri olsa da bu müsamahalı bir kullanımdır. ${ }^{35}$

Risâle yazarına göre, Hatibzâde'nin sözünü ettiği çerçeveden bakıldığında "mahiyet"in umûr-ı âmmeden sayılmaması gerekecektir. Zira mahiyet, yalın haliyle mevcutlara doğrudan yüklemlenemez. Söz gelimi, "mevcut, mahiyettir" demek yerine "mevcut, mahiyet sahibidir"

${ }^{31}$ Cürcânî, Hâşiye 'alâ Şerhi'l-Metâli', (İstanbul: Matbaa-i Âmire, 1277), 15.

${ }^{32}$ Aynı yer.

33 Aynı yer.

34 Bahsi geçen yüklem türleri için bkz. Mehmet Özturan, "Yüklemlemenin Anlamı: Tecrîdü'l-i'tikâd Üzerine Bir İnceleme”, Beytulhikme Felsefe Dergisi, 10/1 (2020), 213215.

35 Hatibzâde, Hâş̧iye 'alâ Hâş̧iyeti't-Tecrîd, 15a-15b. 
denilmektedir. Bununla birlikte, mahiyetin en azından belirli düşünürlerce umûr-ı âmmeden sayıldığı hususunda şüphe yoktur. ${ }^{36}$

Bu noktada, Hasan Çelebî'nin Şerhu'l-Mevâkıf a yazdığı hâşiyesinde mahiyetle ilgili dile getirilen soruna karşı sunduğu çözüm de yazar tarafından şüpheyle karşılanmıştır. Hasan Çelebîye göre mahiyet, çoğunlukla küllî hakikat için kullanılmış ve bu sebeple de "mahiyet lafzı, iltizâmî (gerektirme) olarak küllîliğe delalet eder" denmiştir. ${ }^{37}$ Risâle müellifine göre bu durum da şüpheyle karşılanmalıdır. Zira bir delâlet türü olan iltizâmî delâlette özel anlamda açık lâzım (el-lâzimü'l-beyyin bi'l-ma'na'lehass) muteberdir ${ }^{38}$. Bir diğer tabirle, gerektirenin (melzûm) tasavvurunun gerekenin (lâzım) tasavvuru için yeterli olması gerekmektedir. Mahiyet ile küllîlik arasında ise birinin tasavvurundan diğerinin tasavvurunun gerekmesi gibi bir durum söz konusu değildir.

\section{Sonuç}

Râzî̀nin müstakil bir başlıkla ele aldığı umûr-ı âmmenin ne şekilde anlaşılması ve neleri kapsadığına yönelik yorumlarından birini teşkil eden ve Îcî, Ali Kuşçu gibi isimler tarafından benimsenen özgülük temelli yorumu, Kara Seydî örneğinde olduğu gibi kimi Osmanlı filozoflarınca da

${ }^{36}$ Anonim Umûr-ı Âmme Risâlesi, 110b. Mâhiyetin umûr-ı âmmeden sayılması ile ilgili bkz. Fahreddin Râzî, el-Mülahhas fi'l-hikme ve'l-mantık (İstanbul: Süleymaniye Kütüphanesi, Ragıp Paşa, 877), 97b; Kâtibî, el-Münassas, 187b; Tûsî, Tecrîdü'l-i'tikâd, thk. Muhammed Cevâd el-Hüseynî el-Celâlî (Kum: Mektebü'l-a'lâmi'l-islâmî, 1407), 121; Cürcânî, Şerhu'lMevâkıf, 1/213.

37 Hasan Çelebî, Hâş̧iye 'alâ Şerhi'l-Mevâkıf, (Mısır: Matbaa-i Saâde, 1907), 2/60. Belirtmek gerekir ki, Hasan Çelebî, mezkûr çözümü risâle yazarının belirttiği bağlamdan farklı olarak "mahiyet"in tüm mevcutları kapsayan bir umûr-ı âmme terimi olup olmamasına yönelik dile getirilen bir itirazı destekleyici yan argümana karşı cevap niteliğinde zikretmiştir. Zikredilen itiraz, Cürcânî'nin "mahiyet"in mevcudun üç kısmını da kapsayacak şekilde umûr-ı âmmeden olabilmesini Zorunlu'da mahiyetin varlıktan başka oluşuna bağlamasına yöneliktir. Zira Cürcânî’ye göre mahiyet, Zorunlu'da varlıkla özdeș kabul edildiğinde tüm mevcutlarda bulunan ve dolayısıyla onlara yüklemlenebilen olmaktan çıkacaktır. İtiraz ise mahiyetin ister Zorunlu'nun varlığı ile özdeş olsun ister olmasın onda sâbit olması hasebiyle tüm mevcutları kapsayacağını iddia etmektedir. Nitekim Cürcânî'nin Hâşiye-i Tecrîd'de mahiyeti, mevcutları kapsayan anlamında umûr-ı âmmeden zikretmesi de bu itirazı teyit etmektedir. Tartışmanın detayı için bkz. Hasan Çelebî, Hâşiye 'alâ Şerhi'l-Mevâkıf, 59-60. Ahmednagârî, terimler sözlügüunde mahiyet maddesini açımlarken hükemânın ıstılahında mahiyetin "o nedir?" sorusuna verilen yanıta tekabül edip bu haliyle küllî hakikate delalet ettiğini, bazen de "bir şeyi ne ise o yapan" anlamıyla alınarak hem küllî hem de cüzî hakikati kapsadığını belirtir. Bkz. Abdünnebi Ahmednagarî, Düstûru'l-'ulemâ ev câmi'u'l-'ulûm fî ıstılâhâti'l-fünûn, tsh. Hasan Hânî Fahs (Beyrut: Dâru'l-kütübi'l-'ilmiyye, 2000), 4/136.

|562| 38 Lâzım'ın taksimi ve özel anlamda açık lâzım için bkz. Yezdî, Şerhu't-Tehzîb ma'a hâşiyetihî'l-cedîdeti'l-müsemmâ ferahu't-takrîb (Karaçi: Mektebetü'l-Medîne, 2018), 130131. 
yorumlamalara tabi tutulmuştur. Bu yorumlar arasında belki de en dikkat çekeni, dibacesindeki ifadelerden Kânûnî̀ye ithaf edildiği anlaşllan ve müellifine dair kayıt içermeyen bir umûr-ı âmme risâlesinde yer almıștır. Müellif risâlesini, Mevâkı $९$ ın umûr-ı âmme tanımını Cürcânî șerhi üzerinden okuma ve gerektiğinde Tecrîd ve Metâlit gibi metinlere de müracaat ederek önceki şârih ve muhaşşîlerin dikkatini çekmemiş ve ilk kez kendisi tarafından sunulduğunu öne sürdügü bir iddiayı dile getirmek için kaleme almıştır.

Îcî'nin Mevâkı fta dile getirdiği ve sonrasında şârih Cürcânî gibi düşünürlerce "mevcudun kısımlarına özgü olmayanlar" şeklinde formüle ettiği umûr-ı âmme tanımı, özgülük temelli yorumun baskın olsa da tek yorumu değildir. Tanımda yer alan özgü olmayışın, umûr-ı âmme ile mevcudun kısımlarından hangisine yönelik olduğu ve bu iki alternatifli durumun ne gibi sonuçlar vereceği birtakım düşünürlerce tartışılmıştır. Müellifi meçhul umûr-ı âmme risâlesi, bahsi geçen özgü olmamayı umûr-ı âmme tarafına değil de mevcudun kısımları tarafına yüklem kılmayı tercih etmiş ve buna dil kaynaklı birtakım gerekçeler de getirmiştir. Mevcudun kısımlarının özgü olmamasını umûr-ı âmmenin bir şartı ve ölçütü alan yorum, buna bağlı olarak zâtî zorunluluk ve kıdemin bu şartı ihlal etmemesi sebebiyle umûr-ı âmmeden sayıldığını ve bu sayımın da dolaylı ya da ikincil değil aslî ve doğrudan olduğunu iddia etmektedir.

Risâle yazarı, kendi yorumunu ortaya koyduktan sonra umûr-ı âmme sorununa mahiyet ve kapsam cihetleriyle yön veren önemli düşünürlerin eleştirisine girişmiştir. Bu sadette özellikle Cürcânî ve Hatibzâde'nin ismi öne çıkmaktadır. Yazar, Cürcânî'nin Şerhu'l-Mevâkıf'ta özgülük temelli yorumun umûr-ı âmmenin kapsamına yönelik birtakım sorunlar ortaya çıaracağı şeklindeki ifade ve tutumunu, Hatibzâde'nin ise umûr-ı âmmenin özgülük ve kapsayıcılık temelli yorumları arasındaki farkı belirsizleștimeye yönelik teșebbüsünü eleştiri konusu kılmıştır. Yine o, Cürcânî'nin umûr-ı âmmenin haricî mevcutlara yüklem kılınan şeklinde anlaşılması gerektiğine dair ifadelerinin, Hatibzâde ve Hasan Çelebi gibi isimlerce muhtelif şekilde yorumlanmasını şüpheli karşılamakta fakat bu konuda kendi kanaatini de belirtmemektedir.

\section{KAYNAKÇA}

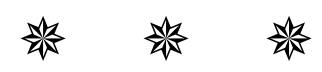

AHMEDNAGARÎ, Abdünnebi. Düstûru'l-'ulemâ ev câmi'u'l-'ulûm fí ıstılâhâti'lfünûn. tsh. Hasan Hânî Fahs. Beyrut: Dâru'l-kütübi'l-'ilmiyye, 2000. 
Anonim Umûr-ı Âmme Risâlesi. Burdur: İl Halk Kütüphanesi, 68, 107b-110b.

APAYDIN, Yasin. "Kara Seydî-i Hamîdî ve Umûr-ı Âmmeye Dair Risâlesinin Tahlil, Tahkik ve Tercümesi”. Darulfunun Illahiyat, 29/2 (2018).

APAYDIN, Yasin. Metafiziğin Meselesini Temellendirmek: Tecrîd Geleneği Bağlamında Umûr-ı Âmme Sorunu. İstanbul: Endülüs Yayınları, 2019.

ARICI, Mustakim. "Bir Otorite Olarak Seyyid Şerif Cürcânî ve Osmanlı İlim Hayatındaki Yeri”. İslam Düşüncesinde Süreklilik ve Değişim: Seyyid Şerif Cürcânî Örneği. ed. M. Cüneyt Kaya. İstanbul: Klasik Yayınları, 2015.

CÜRCÂNî, Seyyid Şerif. Hâşiye 'alâ Şerhi'l-Metâli'. İstanbul: Matbaa-i Âmire, 1277.

CÜRCÂNÎ, Seyyid Şerif. Hâşsiyetü't-Tecrîd. thk. Eşref Altaş vd. İstanbul: Türkiye Diyanet Vakfı İslam Araştırmaları Merkezi, 2020.

CÜRCÂNÎ, Seyyid Şerif. Şerhu'l-Mevâkıf. İstanbul: Matbaa-i Âmire, 1311.

HASAN ÇELEBÎ. Hâş̧iye 'alâ Şerhi'l-Mevâkıf. Mısır: Matbaa-i Saâde, 1907.

HATIBZÂDE, Muhyiddin Mehmed. Hâşiye 'alâ Hâşsiyeti't-Tecrîd. İstanbul: Süleymaniye Kütüphanesi, Fatih, 2926, 1b-388a.

İBN HALDUN. Mukaddimetü İbn Haldun. thk. Mustafa Şeyh Mustafa. Beyrut: Müessesetü'r-Risâle Nâşirûn, 2007.

İBN SÎNÂ. 'Uyûnü'l-hikme. thk. Abdurrahman Bedevî. Kuveyt: Vekâletü'lmatbû'ât, 1980.

ÎCî, Adudüddîn. el-Mevâkıffî 'ilmi'l-kelâm. Beyrut: Âlemü'l-kütüb, ts.

İPŞIRLI, Mehmet. "Hacıhasanzâde Efendi". Türkiye Diyanet Vakfı İslâm Ansiklopedisi. İstanbul: TDV Yayınları, 1996, 14/503.

İZGİ, Cevat. Osmanlı Medreselerinde İlim: Riyâzî ve Tabiî İlimler. İstanbul: Klasik Yayınları, 2019.

ÖZTURAN, Mehmet. "Yüklemlemenin Anlamı: Tecrîdü'l-i'tikâd Üzerine Bir İnceleme". Beytulhikme Felsefe Dergisi, 10/1 (2020).

KÂTİBÎ, Necmeddîn. el-Münassas fí Şerhi'l-Mülahhas. İstanbul: Süleymaniye Kütüphanesi, Şehit Ali Paşa, 1680, 1b-628a.

KÂTiP ÇELEBİ. Keş̧ü'z-zunûn 'an esâmi'l-kütübi ve'l-fünûn. Ankara: Milli Eğitim Bakanlığı, 1947.

KUŞÇU, Ali. Şerhu Tecrîdi'l-'akâid. thk. Muhammed Hüseyin ez-Zâriî̂ erRıdâyî. Kum: Râid, 2014.

MOLLA LUTFİ. es-Seb'u'ş-şidâd. İstanbul: Süleymaniye Kütüphanesi, Carullah, 
1341, 100b-102b.

RÂZî, Fahreddin. el-Mülahhas fi'l-hikme ve'l-mantık. İstanbul: Süleymaniye Kütüphanesi, Ragıp Paşa, 877, 1b-353b.

SÜBKÎ, Tâcüddîn. Mu'îdü'n-ni'am: Makam ve Meslek Ahlâkı. nşr. Harun Yllmaz-Muhammed Enes Midilli. İstanbul: Türkiye Yazma Eserler Kurumu Başkanlığı Yayınları, 2019.

ŞEN, İsrafil. Şerhu'l-Mevâkıf ve Hâşiyeleri Bağlamında Naklî Delilin Kesinliği Problemi. İstanbul: İstanbul Üniversitesi, Sosyal Bilimler Enstitüsü, Yüksek Lisans Tezi, 2020.

TAŞKÖPRÎZÂDE, Ahmed efendi. eş-Şekâ'iku'n-nu'mâniyye fî 'ulemâi'ddevleti'l-'usmâniyye. thk. Seyyid Muhammed Tabâtabâî Bahbahânî. Tahran: Ketabhâne müze ve merkez-i isnâd-i meclis-i şûrâ-yı islâmî, 2010.

TAŞKÖPRÎZADE, Ahmed Efendi. Miftâhü's-Sa'âde ve Misbâhü's-Siyâde fî Mevzûâti'l-'Ulûm. Beyrut: Dâru'l-kütübi'l-'ilmiyye, 1985.

TAŞKÖPRÎZÂDE, Ahmed Efendi. Hâşiye 'alâ Hâşiyeti't-Tecrîd. İstanbul: Süleymaniye Kütüphanesi, Ragıp Paşa, 732, 1b-223a.

TÛSÎ, Nasîruddîn. Tecrîdü'l-i'tikâd. thk. Muhammed Cevâd el-Hüseynî elCelâlî. Kum: Mektebü'l-a'lâmi'l-islâmî, 1407.

YEZDÎ, Abdullah. Şerhu't-Tehzîb ma'a hâşiyetihî'l-cedîdeti'l-müsemmâ ferahu't-takrîb. Karaçi: Mektebetü'l-Medîne, 2018.

YUSUF B. ABDURRAHMAN. Fevâid müte'allika bi'l-umûri'l-âmme. İstanbul: Beyazıt Kütüphanesi, Veliyüddin Efendi, 2186, 160a-162b..

$$
\text { 䊏 的 }
$$

EKLER:

Ek 1: Risâle Metninin Neşri

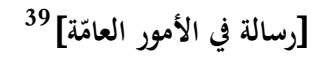

$$
\begin{aligned}
& \text { [107] [بم الله الرّمَمن الرّحيم } \\
& \text { وبه العون } \\
& \text { الحمد للّ الّذي أَبدع الماهيّات من مَكامن العدم إلى فضاء الوجود، واخترع الهويّات من معادن الظّّم إلى مَفْسح العون } \\
& 39 \text { اعتمدنا في النشر على أسس مركز البحوث الإسلامية (ISAM) و على النسخة الوحيدة الموجودة في المكتبة العامة لمدينة بوردور }
\end{aligned}
$$

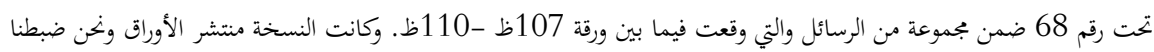

$$
\begin{aligned}
& \text { ورقمّناها حسب سياق المتن. }
\end{aligned}
$$




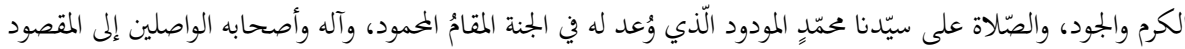

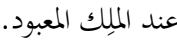

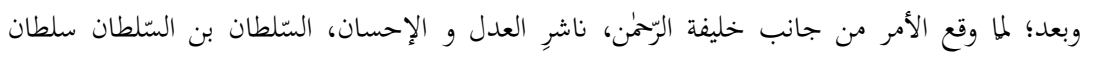

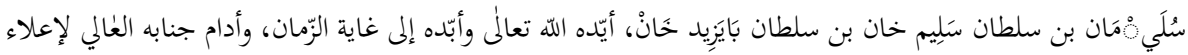

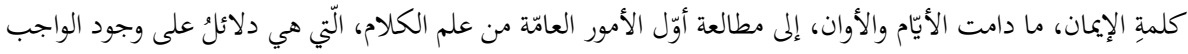

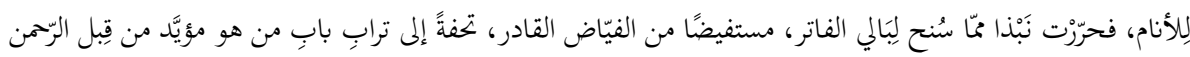

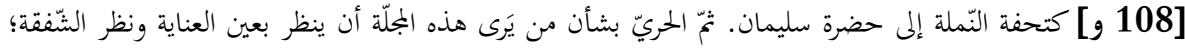

لأنّ نفسي ما أبرّئ عن الخططَ؛ إذ بناء نوع الإنسان على الذّلل. بيت:

$$
\text { فكيف ينهر عن الأغار السائلون وعلى عموم الإشفاق أنفق الرواة والقائلون }
$$

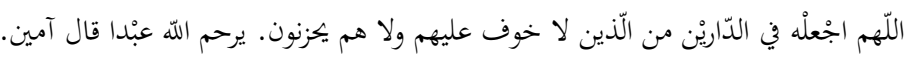

$$
\text { قال صاحب المواقف: - ماقن }
$$

الموقف الثاني: في الأمور العامة؛ أي ما لا يختصنّ بقسْم من أقسام الموجودات التّي هي الواجب والجوهر

[فإما أن يشتمل الاقسام الثلاثة كالوجود والوحدة، فان كل موجود وإن كان كثيرًا له وحدة ما باعتبار

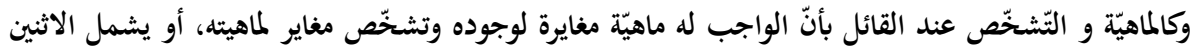
منها كالإمكان الحاص و الحدوث والوجوب بالغير و الكثرة و المعلولية؛ فإنها كلّها مشتركة بين الجوهر والعرض.

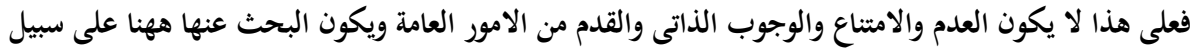

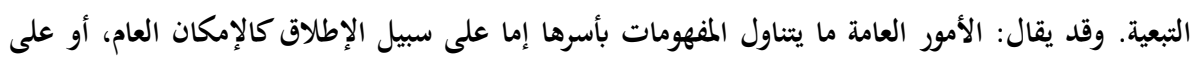

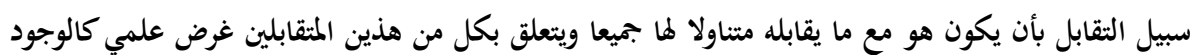
يقول الفقير: في هذا التّعريف معنى لطيف، واستخراج نظيف، لم يتفطّن عليه أحد من الشّراح والمشّين، وهو

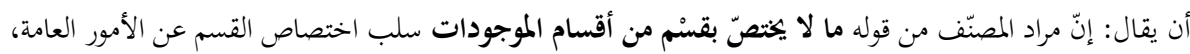

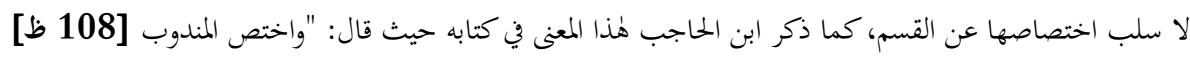

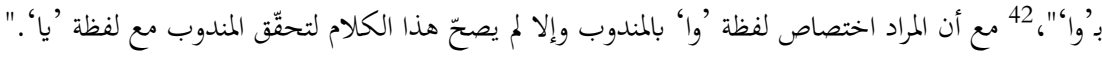
فإذا كان المراد من الاختصاص المسلوب سلب اختصاص القسم عنها، فتحقُق هذا المعنى المراد يكون بأقساحٍٍ 


\section{[110 و ق قال الفاضل الشريف: وكالكثرة.}

فإن قلْتَ: إنّ الكثرة غير شاملة لجميع القسميْن لتحقّق الجواهر الفُردة مع أنّه لا كثرة فيها.

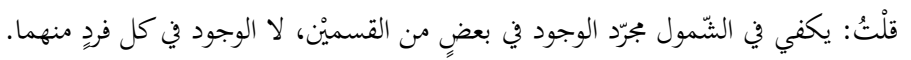
قال قدّس سره: فعلى هذا لا يكون العدم من الأمور العامّة ويكون البحث عنه بالتبّع.

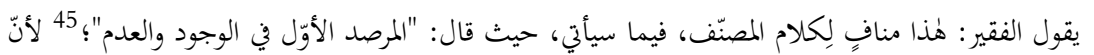

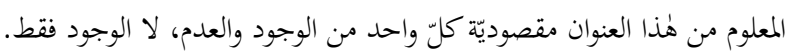
قال: وقد يقال: الأمور العامّة ما يتناول المفهومات إمّا على الإطلاق [أو] على سبيل التّقابل. عبّر الفاضل الشريف هذا التعريف في حاشيته لشرح التجريد بقوله: "والأولى". يقال". وسبب الخلاف في التّعبيريْن غيرُ ظاهرٍ ومحلّ تأمّل.

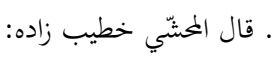

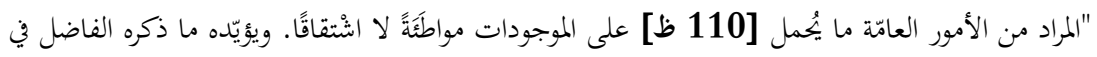

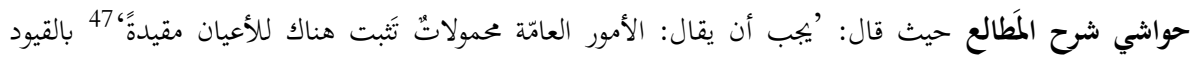

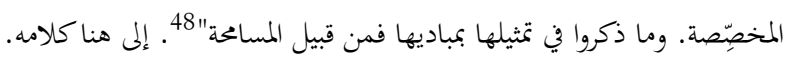

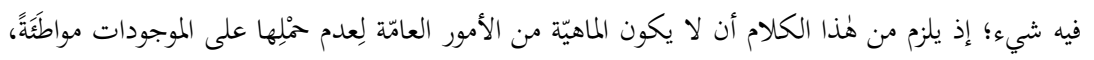

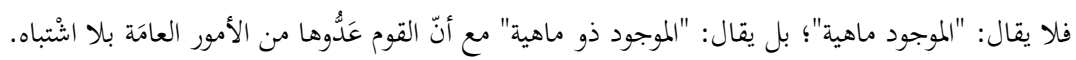

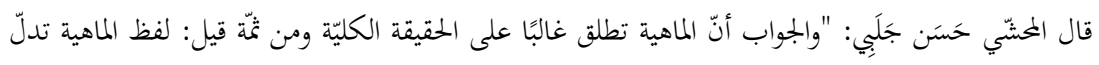
على الكليّة التزامًا".

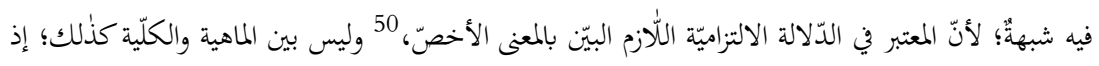
لا يلزم من تصوّر الماهية تصوّرُ الكليّة. ت.

$$
\text { المصادر والمراجع }
$$

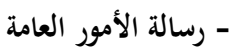
46 حيث قال الجرجاني: والأولى أن يقال: الأمور العامة هي الشاملة لجميع الموجودات إما على الإطلاق أو على سبيل التقابل. انظر

$$
\begin{aligned}
& 47 \text { حاشية على شح المطالع للجرجاني، ص } 15
\end{aligned}
$$

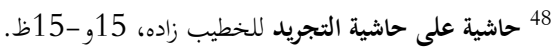

$$
\begin{aligned}
& 49 \text { حاشية على شرح المواقف للحسن جلبي، 60/2 التحريد للخطيب زاده }
\end{aligned}
$$

50 لتعريف أقسام اللازم راجع شرح للحس التهذيب لليزدي، ص 131. 


$$
\begin{aligned}
& \text { مؤلف بجهول } \\
& \text { المكتبة العامة لمدينة بوردور، رقم } 68 .
\end{aligned}
$$

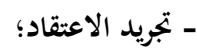

$$
\begin{aligned}
& \text { لنصير الدين الطوسي (ت .672 هـ/1274 م). } \\
& \text { تحقيق: محمد جواد الحسيني الجلالي، مكتبة الأعلام الإسلامي، قم، } 1407 \text { هـ } \\
& \text { - الحاشية على حاشية التجريد } \\
& \text { محيي الدين محمد الشهير بخطيب زاده (ت .901 هـ/ } 1496 \text { م). } \\
& \text { مكتبة سليمانية، قسم فاتح، رقم } 2926 . \\
& \text { - شح التهذيب مع حاشيته الجديدة المسماة فح التقريب }
\end{aligned}
$$

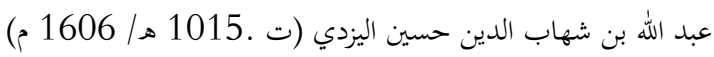

$$
\begin{aligned}
& \text { مكتبة المدينة، كراتشي، }
\end{aligned}
$$

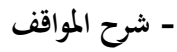

$$
\begin{aligned}
& \text { السيد الشريف الجرجاني (ت .816 هـ/ } 1413 \text { م) } \\
& \text { المطبعة العامرة، اسطنبول، } 1311 \text { هـ. }
\end{aligned}
$$

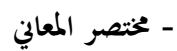

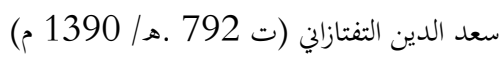

$$
\begin{aligned}
& \text { مكتبة المدينة، كراتشي، } 2016 . \\
& \text { - الحاشية على شرح المطالع }
\end{aligned}
$$

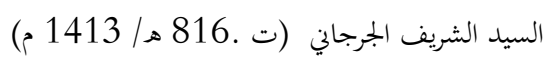

$$
\begin{aligned}
& \text { المطبعة العامرة، اسطنبول، 1277هـ. } \\
& \text { - الحاشية على شرح المواقف } \\
& \text { حسن جلبي بن محمد شاه الفناري (ت .891 هـ/ } 1486 \text { م) } \\
& \text { المطبعة السعادة، القاهرة، } 1907 . \\
& \text { - الكافية في علم النحو والشافية في علمي التصريف والحط } \\
& \text { جمال الدين ابن الحاجب (ت .646 هـ/ } 1249 \text { م) } \\
& \text { تحقيق: صالح عبد العظيم الشاعر، مطبعة الآداب، القاهرة، } 2010 .
\end{aligned}
$$




\title{
Ek 2: Risâlenin Tercümesi
}

\author{
[Umûr-ı Âmme Risâlesi] \\ Rahman ve Rahim Allah'ın adıyla. \\ Yardım O'ndandır.
}

Mahiyetleri yokluktan varlık fezasına çıkaran, hüviyetleri karanlıktan kerem ve cömertlik enginliğine vardıran Allah Teâlâ'ya hamd; sevgiye layık, kendisine cennette övülmüş makam vâdedilmiş efendimiz Muhammed'e ve bihakkın ibadet edilen el-Melik katında maksuda ulaşmış sahabesine salât olsun.

İmdi, Rahmân'ın halifesi, adalet ve ihsan yayan, Sultan Bâyezid'in oğlu Sultan Selim Han'ın oğlu Sultan Süleyman -Allah onu teyid etsin ve zamanın nihayetine dek günler ve vakitler sürdügü müddetçe saltanatını sürdürsün ve iman sözünü yüceltmesi için onu daim eylesin - tarafından kelâm ilmine dair, Zorunlu'nun varlığını insanlara gösteren/kanıtlayan umûr-ı âmmenin başını mütalaa etmem emri gelince karıncanın Süleymân'a hediyesi kabilinden Rahmânın teyid ettiği [padişahın] südde-i seniyyesine ithaf etmek üzere zayıf aklıma gelenleri Feyyâz ve Kâdir olan Allah'tan feyz dilenerek yazdım. Bu risâleyi gören kişinin inayet ve șefkat nazarıyla bakması icap eder. Zira insan türü hataya meyilli olduğundan nefsimi yanlıștan aklayamam.

Beyit:

Talipler nehirlerden mahrum edilir mi,

Şefkatiyle râvi ve fikir erbabı infakı kesmedikçe.

Allah'ım bu fakiri iki cihanda kendilerine korku olmayan ve üzülmeyenlerden eyle! Allah, âmin diyene rahmet eylesin!

Mevâkıfyazarı [Îcî] şöyle dedi: “íkinci mevkıf: Mevcutların kısımları olan Zorunlu, cevher ve arazdan birine özgü olmayan umûr-ı âmme hakkındadır. [Bunlar da varlık, her bir var olan çok da olsa bir birliğe sahip olduğundan birlik, Zorunlu'nun varlığından başka mahiyeti ve mahiyetinden başka taşahhusu olduğunu kabul edenlere göre de mahiyet ve taşahhus gibi (mevcudun) üç kısmını; ya da özel imkân, hudûs, başkasıyla zorunluluk, çokluk ve maluliyet gibi cevher ve arazlar arasında ortak olması sebebiyle iki kısmını kapsayabilir. Buna binaen yokluk, imkansızlık, zâtî zorunluluk ve kıdem umûr-ı âmmeden sayılmayıp ancak başka konularla ilgili/ikincil olması sebebiyle dahil edilmektedir. Şöyle de denilebilir: Umûr-ı âmme, mefhumların tümünü genel imkânda olduğu gibi ya tek başına ya da varlık ve yokluk gibi karşıtı ile birlikte alınarak her birine ilmî bir amacın ilişmesi suretiyle kapsayandır.]"

Fakir şöyle der: Bu tanımda şerh ve hâşiye yazarlarının hiçbirinin farkına varamadığı ince bir anlam ve sorunsuz bir çıkarım vardır. 0 da şöyle ifade edilebilir: Müellif [îcînin], "mevcutların kısımlarından birine özgü 
olmadığı" sözüyle kastı, [mevcutların] kısmının umûr-ı âmmeye özgülügünü olumsuzlamak olup [umûr-ı âmmeyi mevcutların] bir kısmına özgü kılmayı olumsuzlamak değildir. Nitekim İbnü'l-Hâcib bu anlamı kitabı [Kâfiye'de] şu sözlerle zikretmiştir: kıldı."

“Mendubu [kederlenme sonucu yapılan münâda türü] 'vâ' lafzına özgü

Halbuki onun kastı, "vâ" lafzını menduba özgü kılmaktı. Aksi takdirde mendup [vâ lafzı dışında] "yâ" lafzıyla da gerçekleștiğinden bu söylenen doğru olmazdı.

Olumsuzlanan özgü olmaktan kasit, kısmın [umûr-ı âmmeye] özgülüğünü olumsuzlamak olduğuna göre bu anlam şu üç kısımda gerçekleşir:

İlki, varlık örneğinde olduğu gibi, [umûr-ı âmmenin] mevcutların üç kısmını da kapsamasıdır. İkincisi, özel imkânda olduğu gibi iki kısmı kapsamasıdır. Üçüncüsü, zâtî zorunluluk ve kıdem gibi tek bir kısmı kapsamasıdır. [Bu üç kısımda gerçekleşme] her bir durum hakkında "üç kısımdan birinin umûr-ı âmmeye özgü olması olumsuzlanmıştır" denebilmesinden kaynaklanır. Bu açıklamayla, müellif [Îcîye göre] bir kısmın- son örnekte Zorunlu'nun- zâtî zorunluluk ve kıdeme özgü olmasının olumsuzlanmasına binaen bu ikisinin umûr-ı âmmeden sayılma gerekçesi ortaya çıkmıştır.

Buna dayalı olarak Cürcânî'nin -ruhu aziz olsun- [Îcînnin tanımı] üzerine "zâtî zorunluluk ve kıdem umûr-ı âmmeden olmaz" sözüyle detaylandırması müellifin kastına uygun düşmemektedir. Allah Teâlâ işin hakikatini en iyi bilendir.

Aynı şekilde bu açıklamayla, hâşiye yazarı Hatibzâde'ye ait “[îcî”nin] yer verdiği 'mevcutların kısımlarından birine özgü olmayan' ve 'mevcutların tümünü ya da çoğunu kapsayan' şeklindeki iki tanım anlam itibarıyla bir, lafız itibarıyla farklıdır" şeklindeki tahkik sonucu ulaştığı itiraz da giderilmiştir. Nitekim [Hatibzâde] şöyle demiştir:

"Zâhir olan anlam, [tanımla kastedilenin] mevcudun kısımları değil de şahsî fertleri olsa da [mevcudun kısımlarına] yüklemlenmesi gerekir. Zira aklın şahsî fertleri kuşatması ya da onların çoğunu tayin etmesi mümkün olmadığından illiyet ve çokluk gibi umûr-ı âmmeden bazılarının [mevcutların] çoğunu kapsadığı şeklinde yargıda bulunamaz. Bu takdirde, mezkur yorum, Cürcânî’nin "denildi ki" sözüyle dile getirdiği yoruma dönmek olsa da onun "denildi ki" sözüyle yer verdiği bu yorum sonrası nakletmesi dönmediğini gösterir. Ancak şu söylenebilir ki, onun bahsi geçen nakli, sadece mefhumdaki farklılığa binâendir." [Hatibzâde'nin] sözü burada tamamland.

İyi düşünüldüğünde [Hatibzâde'nin] itirazının nasıl giderildiği ortaya çıkar. Zira iki tanımdan sadece "mevcutların tümü ya da çoğunu kapsayanlar" şeklinde ifade edilen ilki itibarıyla zâtî zorunluluk ve kıdemin [umûr-ı 
âmmeden sayılmasına] uygun olması sebebiyle hem lafız hem de anlam itibarıla birbirinden farklıdır.

Cürcânî, şöyle dedi:

"Zorunlu'nun varlığından farklı olarak mahiyeti olduğu ve mahiyetinden farklı olarak da taşahhusu [belirlenimi] olduğunu savunanlara göre mahiyet ve teşahhus gibi".

Fakir der ki: Mahiyet ve taşahhusu "savunanlara göre" ifadesiyle sınırlandırdı. Halbuki varlık [mahiyet üzere] zâit olmasa mahiyet ve teşahhus gibi [mevcutların] üç kısmını kapsayamazdı. Dolayısıyla [Cürcânî'nin] varlı̆̆ı değil de bu ikisini "Zorunlu'da bu suretle olduğunu savunanlara göre" şeklinde kayıtlaması uygun düşmemiştir.

Cürcânî, şöyle dedi:

"Yahut [umûr-ı âmme] özel imkânda olduğu gibi [mevcutların kısımlarından] ikisini kapsar."

Fakir der ki: Bu ifadede küçük bir sorun vardır. Zira [yahut] ifadesi nahiv kitaplarında belirtildiği üzere iki şeyden biri için söz konusudur. Böyle olunca ikinci şık kastedildiğinde "varlık" $n$, ilki tercih edildiğinde ise bu kez “özel imkân"ın umûr-ı âmme dışı kalması gerekecektir.

"Yahut" kelimesinin "ve" anlamında kullanıldığı dile getirilirse buna karşılık şöyle derim: Bunu kabul etmeyiz. Kabul etsek dahi bu kez başka bir yanlış ortaya çıkar. O da umûr-ı âmmenin üç kısmı ve iki kısmı birlikte kapsayanları ifade etmesidir. Zira "ve" mutlak bir araya getiriş için kullanılır. Bu durumun yanlışlığı da açıktır.

Cürcânî şöyle dedi: Çokluk gibi.

Dersen ki: Çokluk, çokluk içermeyen atomların varlığı sebebiyle iki kısmı kapsamamaktadır.

Derim ki: Kapsamada iki kısımdan bazısında bulunma yeterlidir. 0 iki kısmın her bir ferdinde bulunma şartı yoktur.

Cürcânî şöyle dedi: Buna binaen yokluk, umûr-ı âmmeden olmayıp onun hakkındaki araștırma ikincildir.

Fakir der ki: İleride de geleceği üzere bu, musannif [Tûsî'nin] sözlerine aykırıdır. Zira o şöyle demiştir: Birinci bölüm (mersad) varlık ve yokluk beyanındadır. Bu başlıktan sadece varlığın değil varlık ve yokluğun her birinin maksut [ana bahis] olduğu anlaşılmaktadır.

[Cürcânî] dedi ki: [Umûr-ı âmmenin tanımı konusunda] şöyle de denilebilir: Umûr-ı âmme, mefhumları ya tek başına ya da mukabili ile birlikte içine alan şeylerdir.

Cürcânî zikredilen tanımı Tecrîd üzerine yazdığı hâşiyede "daha uygun olan" ifadesiyle burada ise "denilebilir" ifadesiyle vermiştir. İki tabir arasındaki fark, açık olmayıp üzerinde durulması gerekir. 
Umûr-ı âmme ile kastedilen mevcutlara dolaylı değil de doğrudan yüklem kılınanlardır. Nitekim bu durumu [Cürcânî'nin] Havâşî 'ale'lMetâli'deki şu sözleri desteklemektedir: "Şöyle denmesi gerekir: Umûr-1 âmme a'yâna onları sınırlayarak yüklenen yüklemlerdir." [Umûr-ı âmmeye] örnek olarak onların masdar hallerini zikretmeleri müsamaha kabilindendir. [Hatibzâde'nin haşiyedeki] sözleri buraya kadardır.

[Bu sözde] küçük bir sorun bulunmaktadır. Zira bu açıklamaya binaen mahiyetin umûr-ı âmmeden sayılmaması gerekir. Zira o mevcutlara doğrudan yüklem kılınmaz. Dolayısıyla "mevcut mahiyettir" denmeyip "mevcut mahiyet sahibidir" denir. Hâlbuki konunun erbabı ihtilafsız bir şekilde onu umûr-ı âmmeden saymıştır.

[Şerhu'l-Mevâkıf] hâşiyesi yazarı Hasan Çelebi şöyle demiştir: [Sorunun] cevabı, mahiyetin genel olarak küllî hakikat için kullanılır olmasıdır. Bu sebepledir ki, mahiyet lafzı külliliğe iltizâm yoluyla delalet eder denmiştir.

Bunda da şüphe vardır. Zira iltizâm yoluyla delalette özel anlamıyla açık gereken dikkate alınır. Mahiyetin tasavvur edilmesi küllîliğin tasavvurunu gerektirmeyeceğinden mahiyet ile küllîlik arası böyle değildir.

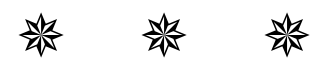




\title{
AN ANONYMOUS TREATISE ON AL-UMUR AL- AMMAH DEDICATED TO SULTAN SULEYMAN THE LAWGIVER: A NEW PERSPECTIVE IN THE CONTEXT OF INTERPRETATION OF IRREDUCIBILITY
}

\author{
Yasin APAYDINa
}

\section{Extended Abstract}

The philosophical and more specifically theological books written in postclassical period of Islamic thought differed from previous philosophical texts in some characteristics. One of them was the manner in which the texts were composed. Arguably the most apparent part which the text of classical period were lack of was the section of al-umür al-ämmah. Although it literally means general things it is equal to general metaphysics which cover the essential attributes of the subject matter of metaphysics, i.e. being qua being.

This article focuses on al-umūr al-āmmah (general metaphysics) discussed in an anonymous treatise dedicated to Suleymān the Lawgiver (1520-1566). By the time of al-Rāzì (d. 606/1210) al-umūr al-ämmah sections began to take a central position in philosophical and theological works. It became an independent field of study in which its meaning and scope was refined. Many thinkers including al-Īcī (ö. 756/1355), Ali Qushjī (d. 879/1474) and Kara Saydī (d. 912/1507) prefered to define al-umūr al-āmmah on the basis of unpeculiarity. For them what makes a thing belonging to the class of concepts known as al-umūr al-ämmah is whether or not it is reducible to one of the three parts of being namely necessary, substance or accident. There were variying views according to the philosophcal and theological diversity among thinkers in defining the direction of reduciblity.

Jurjānī, in his magnum opus Sharh al-Mawāqif interpreted al-Īcīs (ö.

\footnotetext{
a Prof., İstanbul University, yasin.apaydin@istanbul.edu.tr
} 
756/1355) definition of al-umūr al-ämmah which had taken unpeculiarity as a basis of it as "what encompasses topics that are participating in, yet not reducible to, one specific division of being". For Jurjānī the unpeculiarity was equal to encompassing. Although his interpretation was dominant among the commentators there were other opinions which had highlighted irreducibility rather than encompassing.

One of those who insisted the irriducible character of al-umür al-ämmah was the anonymous author of the treatise of al-umūr al-ämmah. He claims that the reception of the theory of irreducibility was not appropriate with its original form introduced primarily by al-Īci in his al-Mawāqif in the very begining of the section devoted to al-umür al-ämmah. For him, the definition of al-umūr al-āmmah in al-Mawāqif is sufficient to cover the concepts as necessity by itself (al-wujub al-zhātī) or pre-eternity (al-qidam). On the other hand, Jurjāni declared that the definition did not cover them as they were reduced to one specific division of being i.e. Necessary being. As fort the author of the treatise of al-umūr al-ämmah, both the necessity by itself and pre-eternity should be regarded among al-umūr al-āmmah.

The author of the treatise argues that what should not be reduced is not alumūr al-ämmah, as expected literally from the text and interpreted by the most of thinkers such as Jurjānī, but rather the parts of existents (aqsām almawjūdāt) namely Necessary, substance and attribute, should not be reduced to al-umür al-ämmah. Based on this idea, he concluded that there is no confliction between to say that the necessity by itself and pre-eternity are of al-umür al-ämmah and that to describe al-umür al-ämmah as what is not reducible. For him, the subject of irreducibility is the part of being not alumūr al-āmmah.

Based on his specific view on al-umūr al-āmmah, he criticized some thinkers who commented al-Īcì's definition. Among them Jurjānī, probably for his influence on later thinkers, is the center of his critics. He commented almost every sentence of him in this short treatise. For example he does not agree with Jurjānī when he described al-umūr al-ämmah as the predicates attributed to the external things (mahmūlāt). He then criticized Ottoman eminent philosopher Hatībzāde Muhyiddīn Mehmed Efendi (d. 901/1496) through his commentary on Tajrìd al-'aqāid of al-Tūsī (672/1274). One of those who is criticized by the author of the treatise, is Hasan Çelebī al-Fenārī through his glosses on Sharh al-Mawāqif of Jurjānī.

The article aims to show that the outlook of al-umür al-ämmah during the $\mathrm{XIV}$ and XV centuries of Ottoman Empire put forward a distinctive 
interpretation of the theory of unpeculiarity. To put the treatise into its right context, I pointed to some texts which indicate the importance placed by Ottoman thinkers to the section of al-umūr al-ämmah with a special reference to the time of Bayezid II. I added the text and its translation into Turkish based on the single copy of it preserved in Burdur Il Halk Kütüphanesi at the end of the article.

Keywords: Islamic philosophy, Ottoman philosophy, Treatise of al-umūr alāmmah, Sharh al-Mawāqif, Hatībzāde.

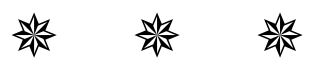

